\title{
ФОРМЫ ПОЛИТИЧЕСКОГО УЧАСТИЯ И ПОЛИТИЧЕСКОЙ АКТИВНОСТИ В СОВРЕМЕННОЙ РОССИЙСКОЙ МОЛОДЕЖНОЙ СРЕДЕ
}

\begin{abstract}
Аннотация: Рассмотрены факторы, определяющие политические ориентации молодежи, конвенциональные и неконвенциональные формы политического участия молодого поколения, политическая специализация. Анализируются сочиально-политические установки и иенности современной российской молодежи. Предпринята попытка описания основных типов сиенариев поведения, лежащих в основе формирования мотивации политического участия российской молодежи. Рассмотрена практика создания и функиионирования молодежного парламентаризма в России: выделены основные формы молодежных парламентов. Определено место современной молодежи как субъекта политики.
\end{abstract}

Ключевые слова: Политология, молодежь, политическая активность, политическое участие, политика, молодежные организачии, парламентаризм, политизация, общество, государство

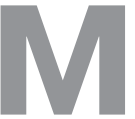

олодёжь всегда стремилась к активной политической жизни. Вопрос о причинах спонтанной молодёжной активности впервые был поднят в 80-е годы XX века. Этот период был отмечен настоящим всплеском интереса к неформальным молодёжным группированиям. Появление новых, открытых социальных идентичностей было выражением надежды на возможность массового участия молодёжи и других прогрессивных сил в преобразовании российского общества. Растущий интерес к отдельным культурным молодёжным практикам стимулировал обращение социологов, политологов, культурологов к качественным методам сбора информации, позволявшим проникнуть глубже за количественные показатели усредненного мнения «большинства». Рос интерес к западному опыту молодежных исследований, технологиям социальной политики в отношении молодежи, переводам и публикациями классических работ в этой области. Однако уже середина и конец 90-х ХХ века интерес к проблеме участия молодёжи в политической жизни страны падает.

С начала нового столетия вновь наблюдается растущий интерес к молодёжной «проблеме», напрямую связанный с особым периодом современной российской истории. Противостояние бывших союзных республик, угрозы «цветных революций», популярность ксенофобских, экстремистско-националистических настроений в молодёжной среде, стихийные поиски объединяющей национальной идеи - все это подталкивает политиков и политологов к переключению внимания с политической элиты на реально действующих акторов, к определению их ресурсов, направленности активностей и прогнозу их последствий.

Выявление мотивационных особенностей политического поведения молодых людей, направляющих свою активность в область политики и пытающихся влиять на неё, принципиально важно в преддверии их вступления в зрелую фазу жизни, в тот период, когда именно их решения будут определять политику в стране. Не требует доказательств утверждение: от того, насколько сформирована у современной молодёжи социально-политическая позиция и развит уровень её политической активности, зависит будущее российского общества. По нашему мнению, выявление факторов и стимулов, определяющих политическую активность молодежи, является одной из важнейших задач сегодня.

За последние годы, на наш взгляд, в результате непродуманной молодёжной политики российского государства произошло отторжение молодого поколения от тех культурно-исторических ценностей, которыми жил и благодаря которым еще живет наше старшее поколение.

Отсутствие в молодёжном сознании идеала зачастую замещается поклонением кумирам шоу-бизнеса или спорта - своеобразной «идологизацией». К тому же этот процесс сопровождается фетишизацией сферы потребления престижных товаров и услуг.

В современной России активизировались различные формы антиобщественного поведения среди молодёжи, такие как экстремизм и шовинизм, которые требуют политического противодействия. Молодёжь по-разному реагирует на экономические и социальные трудности, одни доходят до политического терроризма, другие полностью игнорируют участие в политической жизни общества - не участвуют в выборах, не признают членства в легальных политических партиях.

Исследователи активности молодёжи в контексте политического терроризма ${ }^{1}$ отмечают, что рост экономи-

\footnotetext{
1 Дроздов А.Ю. Агрессивное поведение молодежи в контексте социальной ситуации. // Социологические исследования. -2003. - № 4; Мартыненко Б.К. Политический терроризм: понятие, признаки, классификации. // Северо-Кавказский юридический вестник. - 1995. - № 7; Сериков А.В. Отношение молодежи
} 


\section{Право и политика $1(157) \cdot 2013$}

ческого неравенства людей, социальные и национальные противоречия ведут к разочарованию молодёжи в эффективности законных способов обретения социальных благ, к массовой маргинализации и криминализации, росту социального недовольства.

В то же время, известно, что объективные противоречия интересов, возникающие на этой базе политические конфликты - глубинный источник и стимул политической активности в любых её формах и видах, основная детерминанта, говоря словами М. Вебера, субъективного смысла политического действия.

В связи с этим политические институты современной России должны заниматься проблемами воспитания социально-политической активности молодёжи, которые станут проводниками взвешенной политики, что приведет к преодолению угрозы национальной безопасности общества.

Из-за отсутствия у государства четких и всеми поддерживаемых целей общественного развития, мобилизующих ценностей и идеалов, молодёжь теряет ощущение Родины.

Многие предпочитают реализовать свою активность в неполитических организациях. Основная форма таких организаций - так называемые «тусовки», формирующиеся на основе общих интересов: спортивных, музыкальных и т.д. У этой категории молодежи формируются установки не столько на творческую самореализацию, сколько на пассивное потребление (квазипотребление) образования, культуры и труда.

Ценностные и идейные ориентации молодежи, конечно, в немалой степени производное от того системного кризиса, который существует в России ${ }^{2}$. Очевидно, что происходит разрушение человеческого потенциала в таких жизненно важных сферах общества, как промышленное производство и наука.

Как утверждают некоторые авторы, сегодня пути решения проблем молодёжи лежат в совершенствовании системы государственной молодёжной политики, а также в решении фундаментальных вопросов развития российского общества ${ }^{3}$. Признаки деградации значительной части молодого поколения, только вступающего в жизнь, - тревожные симптомы свидетельствующие о наличии глубокой и системной социальной деградации как результата кризиса универсальных социальных ценностей, общезначимых идеалов, массового развития потребительских интересов.

Ростовской области к событиям в Москве и Беслане. // Путь в науку. Молодые ученые об актуальных проблемах социальных и гуманитарных наук. Вып.5. 4.2. Ростов н/Д., 2004

${ }^{2}$ Карпухин О.И. Молодежь России: особенности социализации и самоопределения. М., 2003. С. 76.

${ }^{3}$ Мяло К.Т. Время выбора: Молодежь и общество в поисках альтернативы. М.: Политиздат, 1991. С. 111.
В литературе среди важнейших факторов, определяющих политические ориентации молодёжи, выделяют прежде всего влияние СМИ. Так, проведенный опрос показал, что СМИ являются главный источником информации для студентов. Данные социологических опросов, проведенных в 2008-2010 гг., находятся примерно в одной плоскости. Самый высокий рейтинг у телевидения - 42,1 \%, далее 35,6 \% - черпают информацию из сети Интернет; далее радио- $12,2 \%$, газеты и журналы - $10,1 \%{ }^{4}$.

Сегодня среди российской молодёжи нет жесткого политического размежевания, и аполитичность действительно выступает существенной чертой, характеризующей молодое поколение. Разуверившись во всех властных структурах, большинство молодых людей индифферентно относится к любым формам социально-политической деятельности. Молодёжь раздроблена не только по возрастным, но и по социальным группам, сильно отличающимся по своим интересам.

В результате новой ситуации, возникшей вследствие запрета политической деятельности в трудовых и учебных коллективах, политика переместилась из производственной и учебной сферы в сферу свободного времени молодежи, и поставила новые молодежные организации в состояние конкуренции с традиционными досуговыми структурами. В конкретных российских условиях эта конкуренция оказалась неравной. Молодёжные структуры не сумели завоевать ни признания, ни авторитета у широких слоев подрастающего поколения. И если около половины молодых людей считают целесообразным существование в России молодёжных организаций, то лишь 7-10\% сами готовы вступить в них.

Чаще всего, с точки зрения программной деятельности, молодёжные союзы идут по пути ухода от политики в сторону выражения профессиональных интересов различных категорий молодого поколения. Среди наиболее крупных - Российская ассоциация профсоюзных студенческих организаций, объединяющая студентов 250 вузов. Выявилась еще одна тенденция: стремление к объединению свойственно преимущественно учащейся (студенческой) молодёжи и молодой интеллигенции. Работающие же в производстве молодые люди не проявляют даже слабой заинтересованности в создании собственных объединений.

Описанные выше тенденции не являются исчерпывающим описанием современной молодёжной среды. Ценностные ориентации неформальных группировок нельзя назвать ни всеобщими, ни ведущими. Однако они являются отражением проблем общества и позволяют прогнозировать уровень и содержание ценностных ориентаций в ближайшие десятилетия.

\footnotetext{
4 Кравченко А.И. Социология. СПб.: Питер, 2010. С. 233.
} 
Как показывают данные социологических исследований, чем масштабнее социальные преобразования, тем сильнее тенденция к образованию неформальных молодёжных группировок. В условиях политической нестабильности подобные объединения представляют значительную опасность, поскольку являются достаточно пластичным материалом и в любой момент могут стать инструментом в деятельности политических организаций радикальной и экстремистской ориентаций 5 .

В стране появилось множество молодёжных организаций, а большинство партий «обзавелись» собственными «молодёжными крыльями», в результате чего у некоторых наблюдателей возникло ощущение заметной политизации российской молодёжи.

Результаты масштабного исследования, проведенного Институтом социологии РАН, указывают на незначительное увеличение части молодёжи, непосредственно участвующей в политической деятельности (с 1 до 2\%). Примерно на том же уровне, что и 15 лет назад, остается число молодых россиян, активно интересующихся политикой (14\%). Но одновременно почти на $20 \%$ сократилась доля молодёжи, которая «факультативно» интересуется политикой («от случая к случаю»), и с трети почти до половины - не интересуется вовсе. Для старшего поколения также характерно снижение интереса к политической жизни, однако здесь заметно больше тех, кто политикой в той или иной степени интересуется, и соответственно меньше тех, кто такого рода интереса не проявляет (29 и 49\% $)^{6}$.

По данным социологических опросов, большая часть молодёжи полагает, что выборы как социальный институт малозначимы для достижения общественного блага. На сегодняшний день среди молодых людей весьма высок процент полностью политически индифферентных: 43\% политикой не интересуются в принципе.

Рассуждения о политической пассивности российской молодёжи, сопровождаемые тезисом о значительном потенциале её влиянии на ход развития общества, одна из наиболее популярных тем современных публикаций, посвященных проблемам молодого поколения. В то же время социологические исследования, проводимые в различных регионах России, не подтверждают однозначно тезис о растущей политической и гражданской апатии в молодёжной среде. Опираясь на упомянутые данные, более

\footnotetext{
${ }^{5}$ Кравченко А.И. Социология. СПб.: Питер, 2010. С. 233.

${ }^{6}$ Молодежь новой России: Аналитический доклад Института социологии РАН. Подготовлен в сотрудничестве с Представительством Фонда имени Фридриха Эберта в Российской Федерации. М., 2007.

${ }^{7} \mathrm{O}$ повышении правовой культуры молодежи, активизации её участия в избирательном процессе и опыте работы избирательных комиссий субъектов Российской Федерации в этом направлении // Вестник ЦИК. 2002. № 7. С. 59.
}

справедливо было бы говорить об изменении мотивации и форм политического участия.

Так, согласно данным опроса молодых людей в возрасте 16-29 лет, проведенного сотрудниками Аналитического центра Юрия Левады 26 февраля-2 марта 2007 г. в 12 городах России, в целом, молодёжь позитивнее, чем все населении России, оценивает курс развития страны. При этом желание видеть свою страну «великой державой, которую уважают и побаиваются другие страны», разделяют чуть меньше трети молодых жителей России, вдвое чаще молодёжь предпочитает статусу великой и сильной державы высокий уровень жизни в стране. В этой части распределения молодёжных ответов весьма близки к общероссийским.

Однако - и в этом состоит важная особенность как молодёжи, так и российского населения в целом - опрошенные чувствуют себя значительно отчужденными от власти, а потому скорее равнодушны к её действиям. Так к решениям, принимаемым «наверху», заинтересованно относится лишь треть опрошенных (34\%); чуть больше, $40 \%$, считают, что эти решения серьезно влияют на их жизнь. Основные формы, в которых выражается внимание молодых россиян (как и россиян в целом) к политике, формы пассивные: лицезрение политической жизни, как она представлена в масс-медиа, и обсуждение увиденного с друзьями и близкими. В политических акциях за последние три года участвовали $3 \%$ опрошенной городской молодёжи, в политических партиях состоят 4\%, в организации предвыборных кампаний $-5 \%{ }^{8}$.

В то же время отмечается интерес молодёжи к политическим организациям. Практически каждая политическая партия стремится иметь при себе молодежное крыло. «Идущие вместе» и «Идущие без Путина», «Наши» и «Пора», «За Родину» и Евразийский союз молодежи, молодежные отделения СПС и «Яблока», «Единой России» и КПРФ, НБП Эдуарда Лимонова и партия «Новые правые», Российский союз молодежи и Российский коммунистический союз молодежи.

По мнению экспертов, особенность молодёжных организаций состоит в том, что они легки на подъем, но недолговечны. Поднимается определенная волна общественных настроений, появляется какая-то организация. Волна спадает - организации нет. Политолог А. КараМурза объясняет недолговечность молодёжных организаций по-другому: «Они поколенческие. Идет обычная смена поколений. Какая-то организация закрывается, появляется другая». В то же время столь высокая активность молодежи, по мнению эксперта, закономерна - в условиях фактического отсутствия многопартийности в стране по-

\footnotetext{
${ }^{8}$ Городская молодежь и актуальная политика. По заказу Гражданского пула «Право на выбор - 2008» // http: www.sovetpamfilova. ru.election
} 


\section{Право и политика 1 (157) 2013}

явление большого числа не только молодежных, но и, например, пенсионерских организаций вполне естественно9.

Так, например, в 2007 году появилось новое движение «Победа» - молодежное крыло партии «Справедливая Россия». Это уже вторая молодежная организация, появившаяся у этой партии. У «Справедливой России» существует молодежное крыло - «Молодые социалисты России». Интересно отметить, что лидеры двух крыльев придерживаются противоположных политических взглядов. В самой «Справедливой России» ничего страшного в этих противоречиях не видят ${ }^{10}$.

Безусловно, молодёжь, и в первую очередь студенчество, - это очень привлекательная часть электората. Пока, несмотря на свою активность, она по-прежнему плохо ходит на выборы и нечасто вступает в политические партии, у которых непонятная идеология и нет серьезных стратегических программ. Политически-активная часть молодёжи ходит на выборы или каким-либо иным способом проявляет свою позицию. Как правило, это радикально настроенная, оппозиционная часть политизированной молодёжи.

Важно отметить, что процесс формирования политической активности молодёжи можно представить как процесс закрепления в сознании молодых граждан определенной системы ориентации на соответствующие ценности, нормы и образцы политического поведения, в рамках которой существует более устойчивое ядро, обеспечивающее преемственность политической культуры, и менее устойчивые, изменяющиеся ориентации.

Сравнительно невысокий интерес молодёжи к политике понятен и во многом объективно обусловлен. Прежде всего тем, что спектр жизненных интересов, особенно подростков и юношества, локализован на проблеме вхождения во взрослую жизнь, а социальный опыт ограничивается пока межличностными и внутрисемейными коммуникациями. Но по мере увеличения социальных связей (институт, армия, работа и т.д.) происходит перераспределение жизненных интересов в сторону общественного и политического участия.

Так, в младшей возрастной группе молодёжи 14-17 лет в целом интерес к политике в той или иной степени демонстрируют 41\%, в средней (18-24 года) - 48\%, в старшей (25-30 лет) - 57\%. Причем в старшей группе доля интересующихся политикой превосходит число тех, кто ею не интересуется (57\% против 42\%). Также заметно больший интерес к политике проявляет моло-

${ }^{9}$ Кара-Мурза А.А. Цит. по: Политическая активность молодежи растет// Деловая пресса, Политический журнал. - 2005. - № 19.

${ }^{10}$ Козенко А. Молодежь рвет на части «Справедливую Россию»// Газета «Коммерсантъ» №29 (3605) от 22.02.2007. дёжь, которая довольна своим материальным положением (по сравнению с теми, кто оценивает это положение со знаком «минус») $)^{11}$.

Можно выделить две условные категории молодых людей: к одной из них относятся те, кого можно признать политически пассивными. Если эта категория и участвует, то предпочитает конвенциональные формы политического участия (голосование). Неконвенциональные виды политической активности оказываются практически неприемлемыми. Другая категория включает тех, кто склонен к активному политическому участию. Зачастую эта категория в большей мере склонна к неконвенциональным действиям, считая, что они могут быть вполне эффективными.

Следует отметить, что к конвенциональным формам относят: абсентеизм, чтение о политике в газетах, обсуждение политических сюжетов с друзьями и знакомыми, голосование, работу по продвижению имиджа политической партии или кандидата, убеждение окружающих голосовать определенным образом, участие в митингах и собраниях, обращение во властные структуры или к их представителям, активность в качестве политического деятеля (выдвижение кандидатуры, участие в выборах, работа представителя руководящего звена партии или другой организации, работа депутата, министра и т.д.).

Неконвенциональные формы: подписание петиций, участие в неразрешенных демонстрациях, участие в бойкотах, отказ от уплаты налогов, участие в захвате зданий, предприятий и сидячих забастовках в их стенах, блокирование дорожного движения, участие в стихийных забастовках.

Аполитичность и неконвенциональное поведение можно объяснить следствием низкой лояльности, характерной для политической культуры молодежи. Неэффективность системы снижает желание молодёжи поддержать её «конвенциональными» способами, то есть голосуя на выборах. Низкий уровень доверия к существующим политическим институтам подталкивает к неконвенциональным формам деятельности.

Утверждать, как это зачастую делается, что аполитичность современной молодежи носит тотальный характер, было бы неправильно. Более трети молодых россиян (34\%) регулярно смотрят новости по телевидению, а еще $60 \%$ - иногда делают это. Каждый десятый (11\%) живо интересуется аналитическими программами о современной политической и экономической жизни страны, а еще $51 \%$ опрошенных эти программы смотрят эпизодически. Более четверти молодых россиян (28\%) постоянно читают

\footnotetext{
11 Молодежь новой России: Аналитический доклад Института социологии РАН. Подготовлен в сотрудничестве с Представительством Фонда имени Фридриха Эберта в Российской Федерации. M, 2007.
} 
печатную периодику (газеты, журналы) ${ }^{12}$. Учитывая то, что многие черпают информацию из сети Интернет, становится очевидным, что современная молодёжь «в курсе» того, что происходит как в стране, так и за её пределами. Другое дело, что у современной российской молодёжи помимо политики есть множество других сфер и областей приложения своей энергии и активности.

Социально-политические установки молодёжи приходят в противоречие с политической пассивностью, нежеланием поддержать политическую систему, которая также создавалась по либеральному образцу. Схожая ситуация наблюдается и с интересом к политическим событиям.

«Культурная рациональность» подсказывает молодым людям, что в рамках новой политико-институциональной системы интерес к политике не является необходимым атрибутом социальной жизни. Возможно, интерес к политике был бы более оправдан, если бы существующая политико- институциональная система предоставляла больше стимулов к подобному интересу. Базовые нормы политической культуры слабо выражены в ценностной системе молодежи. Видимые формы политического поведения не всегда могут служить адекватными индикаторами степени сформированности политической активности. В этом аспекте особое значение приобретает её ценностное содержание.

Политические ценности молодых людей можно в целом считать либеральными. Поэтому, если новой политической системе удастся стать эффективной, политическое поведение молодых россиян также может приблизиться к демократическим образцам. Гражданская культура формируется лишь в том случае, если граждане сами заинтересованы в участии в политической жизни страны. На ранних этапах становления новой политической системы определяющую роль в поддержании лояльности общества играют «коллективные» стимулы. Идеология, ценности идентичности оказываются важнейшими факторами, определяющими политическое развитие после изменения политического режима в стране. Молодое поколение, социализирующееся в этот период, воспринимает «коллективные» стимулы как первоочередную ценность. Однако затем становится ясно, что без эффективных экономических «выплат» легитимность новой политической системы подвергается опасности.

Можно предположить наличие нескольких основных типов сценариев поведения, которые лежат в основе формирования мотивации политического участия российской молодёжи:

\footnotetext{
${ }^{12}$ Молодежь новой России: Аналитический доклад Института социологии РАН. Подготовлен в сотрудничестве с Представительством Фонда имени Фридриха Эберта в Российской Федерации. M., 2007.
}

- ориентация на достижение успеха. Следует признать, что мотивы карьеры - одни из наиболее ярко выраженных мотивов участия молодежи в политических организациях;

- ориентация на значимых других, поддерживаемая Сильно развитой у молодежи потребностью в аффилиации, когда вступление в политическую организацию объясняется, прежде всего, влиянием друзей, ранее ставших её членами;

- $\quad$ активный протест против сложившихся в обществе политико-экономических реалий, что, как правило, связано с устойчивой неудовлетворенностью существенных личностных потребностей.

Следует учитывать тот факт, что политизирующаяся молодёжь находится под влиянием родителей, которые воспитывались еще в советский период и политических институтов. Единого для любой ситуации механизма, активизирующего ценности, сегодня не существует. Возникающие противоречия решаются, как правило, спокойно, в зависимости от иерархии ценностей и от степени активизации различных ценностей в ситуации. Российскому обществу, пережившему серьезную смену системы ценностей, пришлось столкнуться с конфликтом ценностей.

Можно сделать вывод о том что, степень политического участия молодежи в политической жизни страны, так же как и общества в целом, в достаточно высокой степени фрагментирована. Отдельные группы молодёжи отличаются друг от друга интересом к политике, уровнем включенности в политическую жизнь, ориентациями на различные идейно-политические течения современной России. Но все эти различия пока не носят характер острого антагонизма и не приводят к достаточному уровню политизированности.

Одним из положительных факторов вовлечения молодёжи в политическую жизнь страны следует считать создание молодёжных парламентов.

В ряде субъектов Федерации молодёжные парламенты созданы при органе законодательной, либо исполнительной власти. Так, в Свердловской области с 2002 г. действует Общественная молодежная палата при Областной Думе Законодательного Собрания Свердловской области, которая является совещательным и консультативным органом. В Республике Карелия молодёжный парламент является экспертным, консультативным и совещательным органом по вопросам государственной молодёжной политики при органе исполнительной власти, осуществляющем выработку молодёжной политики. В целом ряде российских городов действуют молодежные парламенты, в частности, в городе Лангепасе Ханты-Мансийского автономного округа - Югры действует Молодёжная дума. При органах местного самоуправления созданы парламенты в городах 


\section{Право и политика $1(157) \cdot 2013$}

Архангельск, Волжский, Екатеринбург, Иваново, Котлас, Новодвинск, Северодвинск и других ${ }^{13}$.

Учитывая опыт развития молодёжного парламентаризма в Российской Федерации, прежде всего, региональный, можно выделить следующие основные формы молодёжных парламентов:

1. Молодёжные парламенты, созданные при органах законодательной (представительной) власти. Молодёжные парламенты создаются законодательным (представительным) органом государственной власти субъекта Федерации и действуют на основании положения, утвержденного постановлением данного органа. По своему статусу молодёжный парламент является общественным совещательным (консультативным) органом. Он в определенной мере участвует в разработке нормативных правовых актов в сфере государственной молодёжной политики, осуществляет взаимодействие с соответствующими комитетами, комиссиями, депутатами органа законодательной власти.

Приведенная организационная модель молодёжного парламента предполагает, как правило, избрание членов молодёжного парламента от максимально возможного количества территорий, образовательных учреждений, молодёжных общественных объединений и т.д. Принятие регламента молодёжного парламента, в котором определяется порядок его работы, осуществляется самостоятельно молодежным парламентом. В структуре молодёжного парламента формируются комитеты, комиссии и другие рабочие органы, перечень и состав которых определяется регламентом и иными внутренними актами молодёжного парламента.

2. Молодёжные парламенты, созданные при органах исполнительной власти (в отдельных случаях наряду с молодёжными правительствами). Практически молодёжные парламентские структуры создаются при главе администрации субъекта РФ, мэре города, исполнительном органе по молодежной политике. Но само понятие «молодёжный парламент» подразумевает представительную природу данной структуры. Это, в свою очередь, делает целесообразным организацию взаимодействия молодёжных парламентов с органами законодательной власти. При органах исполнительной власти, прежде всего, высшем исполнительном органе субъекта Федерации или непосредственно при высшем должностном лице (руководителе высшего исполнительного органа) субъекта Федерации представляется целесообразным формирование молодёжного правительства. Данная взаимосвязь обеспечивает хорошую практику будущих потенциальных управленцев

\footnotetext{
${ }^{13}$ О повышении правовой культуры молодежи, активизации её участия в избирательном процессе и опыте работы избирательных комиссий субъектов Российской Федерации в этом направлении // Вестник ЦИК. 2002. № 7. С. 59.
}

и может быть полезна в деятельности государственных и муниципальных органов, способна обеспечить большую взаимосвязь данных органов с политизирующимся обществом в части такого недостаточно представленного в органах власти его сегмента, как молодёжь. Молодёжное правительство целесообразно учреждать постановлением высшего должностного лица, либо высшего исполнительного органа субъекта РФ, которое определит основные формы его участия в работе органов исполнительной власти. Так, в Москве на время отпуска министров Правительства Москвы был сформирован молодёжный кабинет из числа лучших студентов высших учебных заведений Москвы, отобранных посредством открытого конкурса с последующим временным назначением.

3. Молодёжный парламент - региональная (муниципальная) программа по работе с молодёжью, реализуемая органами государственной власти субъекта Федерации с участием одного или нескольких молодёжных общественных объединений. Данная модель не всегда предполагает формирование молодёжного парламента как чётко организованной структуры. Речь идет о функционировании молодёжного парламентаризма в качестве одного из методов работы органов власти с общественными объединениями. Помимо заседаний молодёжного парламента, работы его внутренних структур (комитетов и т.д.), используются такие формы, как общественные молодёжные приемные, организация мониторингов в молодежной среде, создание теле-и радиопередач, ведение рубрик на страницах периодической печати, организация клубов, диспутов, рекламных кампаний и т.п. А целью соответствующих программ, на наш взгляд должно быть создание возможностей для молодёжи разных политических взглядов участвовать в общественно-политической жизни, в процессе принятия государственных решений и обеспечения контроля за их исполнением.

Вот почему по нашему мнению совершенствование деятельности молодёжных парламентов, может обеспечить принятие такого закона Российской Федерации, по которому в этих парламентах и правительствах была представлена на равных молодёжь разных политических взглядов. В таком законе законах целесообразно установить цели, задачи, принципы и компетенцию молодежных парламентов и молодежных правительств, как в центре, так и в регионах при законодательных и соответственно исполнительных органах государственной власти и местного самоуправления. В настоящее время молодёжные парламентские структуры могут создаваться: при федеральных органах государственной власти (Федеральном Собрании Российской Федерации); при органах государственной власти субъекта Российской Федерации (при законодательном органе (Думе, Совете, Собрании); высшем должностном лице субъекта Российской Федерации, правительстве (администрации); органе по молодежной 
политике); при законодательных или исполнительных органах местного самоуправления (выше уже было сказано о приоритетности создания молодёжных парламентов при представительных, а не исполнительных органах).

Говоря о проблеме повышения уровня осуществления государственной власти, на котором целесообразно создание молодёжных парламентов и молодежных консультативных органов, следует отметить, что создание таких молодёжных органов целесообразно осуществлять как на уровне центра, так и на уровне субъектов РФ вплоть до муниципальных образований. В этих целях, на наш взгляд, необходимо:

Во-первых, установить всероссийские выборы в молодёжный парламент федерального уровня по аналогии с выборами в Государственную Думу, хотя, с организационной точки зрения, это потребует чрезмерных финансовых затрат. Конечно, аналогичная процедура комплектования в определенной мере будет означать претензию на создание альтернативного представительного органа, который в молодёжной среде может быть противопоставлен Государственной Думе, что в воспитательном аспекте может привести к негативному восприятию молодыми людьми «взрослых» органов представительной власти и снижению их активности в выборах представительных органов публичной власти. Но данная цель, на наш взгляд, в целом оправдывает затраченные средства для ее достижения.

Во-вторых, упростить процедуру комплектования корпуса молодых парламентариев посредством установления равных квот от политических молодежных организаций. Тогда на муниципальном и на региональном уровне можно привлечь практически все молодежные объединения и учебные заведения и тем самым обеспечить достаточно высокий уровень представительности молодёжного парламента. К тому же в масштабе всей России можно избежать «перекосов», не допуская перевеса одних молодежных объединений над другими. При этом, где бы ни находился молодёжный парламент, его работа потребует активности всех его членов, особенно на местах: в городах и районах.

В-третьих, укрепить веру в необходимость формирования общероссийского молодёжного парламента посредством правового воспитания молодёжи и привлечения её к участию в делах государства.. Ведь молодые люди с 18-летнего возраста участвуют в голосовании на выборах всех уровней и вправе формировать представительные органы государственной власти, прежде всего, Государственную Думу Федерального Собрания Российской Федерации, избирать выборных должностных лиц. Более того, граждане России, достигшие 21 года, могут сами стать кандидатами в депутаты представительных органов, в том числе, Государственной Думы. Это более традиционный и весьма эффективный механизм участия в делах государства, то есть в государственной власти.
Полагаем, что функционирование федерального молодёжного парламента, построенного по аналогии с региональными и муниципальными молодежными парламентами, существенно повысит политическую активность современной молодёжи. Основные региональные или муниципальные молодёжные общественные объединения, консолидируя значительную часть молодёжи своего региона, будут иметь четко выраженные основные направления реализации интересов молодёжи региона, прежде всего, через социально значимые проекты.

Молодёжный парламентаризм достаточно новое явление российской политической действительности. Среди авторов существуют разные мнения о целесообразности такой организации. Вряд ли можно, например, согласиться с утверждением того, что поскольку молодёжный парламент является преимущественно консультативным органом, следовательно реализация или даже эффективное участие в общероссийских социально значимых проектах станет непосильной задачей для молодежного парламента ${ }^{14}$. На наш взгляд участие молодёжных парламентов в нормотворческой деятельности, даже если оно ограничится лишь сферой государственной молодёжной политики, будет достаточно эффективным, что обосновывает целесообразность такой формы участия молодёжи в политических процессах и способствует повышению уровня её политической активности.

С января 2002 г. реализуется проект «Молодёжная Дума России». Дума является молодёжной парламентской структурой Москвы и ряда иных субъектов РФ, представляющей собой механизм обсуждения общественнополитических вопросов молодежью. Но реализовать заявленную цель - создание коммуникативной площадки для молодёжи разных регионов и политической ориентации и выработки согласованных решений - ей практически не удается. Поскольку принятие и реализация согласованных решений - прерогатива государственных органов, данной структуре целесообразно было бы ограничиться организацией широких обсуждений молодёжью общественно-политических вопросов, в том числе по развитию молодежного парламентаризма в различных регионах и муниципалитетах.

В качестве механизма развития молодёжного парламентаризма следует отметить необходимость разработки программ его развития во всех субъектах Федерации. Такие программы целесообразно принимать и на уровне муниципалитетов (городов и районов). В программах должны быть представлены основные направления обеспечения развития молодёжного парламентаризма. В части

\footnotetext{
14 Чертков А.Н., Артамонова Н.В. Региональный опыт функционирования «молодежного парламентаризма» как механизма развития правовой культуры российских избирателей // Журнал российского права. - 2008. - № 1. С. 54.
} 


\section{Право и политика 1 (157) 2013}

организационного обеспечения требуется закрепление необходимости поддержки инициатив создания молодёжных парламентских структур органами по молодёжной политике, законодательной властью, избирательными комиссиями субъектов Федерации. Целесообразно заключение договоров между заинтересованными сторонами на региональном уровне - между органами по молодёжной политике субъекта РФ, органами законодательной власти, избирательной комиссией субъекта РФ, региональными общественными объединениями; на муниципальном уровне - между представительными органами, органами по делам молодежи, избирательными комиссиями, общественными объединениями.

Можно согласиться с мнением Минобрнауки России о целесообразности создания консультативных групп на базе аппаратов молодёжных парламентов субъектов Федерации, состоящих из двух частей - мобильной и стационарной. Первая часть может быть ответственна за проведение обучающих семинаров, консультаций, сбора информации, тренинговой работы в конкретном субъекте Российской Федерации, где создается или действует молодёжный парламент. Стационарная же часть должна нести ответственность за анализ информации, подготовку тренингов, информационных и статистических материалов, осуществляет связь с каждым молодёжным парламентом субъекта Российской Федерации, организует информационный обмен .

Большое значение имеет также политическая специализация, если её рассматривать как процесс включения молодого человека в политическую систему. Политизация молодёжи, как уже отмечалось выше, является одним из факторов, оказывающим влияние на уровень электоральной активности молодых людей. Центральный тезис заключается в том, что уровень активности молодых людей на выборах напрямую зависит от того, насколько они включены в политический процесс, в активную политику, насколько молодые избиратели чувствуют сопричастность к происходящим политическим процессам. Только при наличии фактора включённости в активную политику акт голосования приобретает политический смысл.

Полагаем, что большинство проблем порождают в первую очередь сами молодые парламентарии, их низкая социально-политическая активность. Для развития системы молодёжного парламентаризма и повышения активности молодежи сегодня была бы актуальной подготовка и запуск новых образовательных программ для молодых парламентариев. Целесообразно также стимулировать развитие молодёжных парламентов регионов посредством внутренней конкуренции. Мало того, что сами молодёжные парламенты будут стимулироваться, стимулироваться к взаимодействию с ними будет также и политическая элита регионов для того, чтобы больше внимания уделять политической активности молодых людей.
Если молодые люди видят, что по их предложениям вносятся изменения в законодательство, принимаются конкретные меры, они начинают понимать, что их голос на самом деле влияет на принятие политических решений. Этот фактор многократно повышает активность как молодых парламентариев, так и молодых людей, с которыми они общаются, стимулирует их обращаться в молодежные парламенты с предложениями по самым разным вопросам социально-экономической жизни.

Можно уверенно говорить о повышении политической активности на выборах именно в молодёжной среде, если в состав участковых или территориальных избирательных комиссий входят представители от молодёжи. Однозначно можно говорить и о необходимости этой тенденции в дальнейшем, потому что фактически уже назрел вопрос о формировании кадрового резерва для избирательных комиссий.

В необходимости структуры, которая решала бы задачи по нравственному и политическому воспитанию молодёжи в русле развития её политической активности, сегодня нет сомнений. Попытки решать их молодёжными отделениями современных политических партий или иными, близкими к партиям молодёжными объединениями, целесообразно, на наш взгляд, дополнить эти попытки еще и системой молодёжного парламентаризма. Молодёжный парламент по определению должен объединять представителей различных партий, объединений и даже тех молодых граждан, которые в таковых не состоят, поскольку молодёжный парламентаризм представляет собой комплексное явление в сфере взаимодействия государства и современного общества. Основными направлениями его выражения являются политико-правое воспитание молодёжи и участие молодых граждан в делах государства.

Сказанное еще раз подтверждает, что именно политическая активность имеет принципиальное значение в становлении молодёжи как субъекта политики, обретении ею соответствующих умений и навыков, а в связи, с этим соответствующих прав и обязанностей. С одной стороны, молодёжь усваивает определённые образцы поведения, социальные нормы и ценности, характерные для определённого общества и государства. С другой - общество и государство, предоставляя молодому поколению вышеперечисленное, способствует его интеграции в систему политических отношений и в деятельность политических институтов, то есть в конкретные политические процессы, происходящие непосредственно или опосредованно в том или ином обществе и государстве, в том числе и в современной России.

Проведенный анализ позволяет определить место современной молодёжи как субъекта политики. Молодёжь представляет собой социально-возрастную группу, переживающую период становления психофизиологической, социальной и политической зрелости, адаптации к ис- 
полнению социально-политических ролей взрослых. При этом возрастной диапазон рассматриваемой социальной группы «молодежь» определяется в основном лицами в возрасте от 14 до 30 лет $^{15}$

Основываясь на проведенном анализе категории «политическая активность» ${ }^{16}$, можно дать ей следующее определение: политическая активность - это вся совокупность действий индивидов и соииальных групп, направленных на совершенствование политической системы общества и изменение своего политического статуса. При этом необходимо учитывать взаимосвязь политической активности общества и личностной активности по совершенствованию существующей политической системы.

Политическая активность личности проявляется, прежде всего, в политической её деятельности, в политическом поведении.

Представляется, что политическую активность следует рассматривать в единстве и взаимообусловленности двух компонентов: материальных (реальное изменение политических отношений) и духовных (аккумуляция и трансляция политического знания и опыта, обмен информацией, межгрупповая и межличностная координация и пр.).

При этом определяющей является политико-поведенческая категория, которая соединяет политическую активность социального субъекта с внешним миром посредством его «мотивов» и «установок». В этом аспекте под политическим поведением мы понимаем такой тип активности, который, будучи обусловленным политической средой, направлен на самого субъекта и выражает его состояние в процессе действия.

Таким образом, политическая активность личности зависит не только от её политической позиции, тесно связанной с ориентацией на определенные политические ценности и идеологические установки, но и от реальных действий этой личности в той или иной политике. А потому, резюмируя сказанное, можно утверждать, что превращению индивида в сознательный и активный субъект политики способствует, прежде всего, конкретная политическая система общества, которая не только предоставляет ему мотивации к активности действий в той или иной политической силе и создает реальные возможности для участия в политической жизни, но и обеспечивает индивида необходимыми знаниями и навыками практической деятельности, формируя у него

15 О стратегии государственной молодежной политики в РФ: распоряжение Правительства РФ от 18 декабря 2006 г. №1760-р // Собрание законодательства РФ. - 2006. - №52, ч. III, ст. 5622. - c. 16017-16026.

${ }^{16}$ Киричек, А.И. К вопросу о дифференциации содержания категорий политическая активность, политическое поведение и политическое участие/ А.И. Киричек // Общество: политика, экономика, право. - Краснодар: ИД «ХОРС», 2011. - №3. - С. 34-37. способности к пониманию политической действительности и самоопределению в ней на основе адекватного отношения к политическим реалиям.

Проведенный нами анализ позволяет заключить, что основой, ядром политической активности является вся система поведенческих установок, в обществе и государстве, в том числе, и в современной России, отражающих отношение к политическим институтам и процессам.

Политическую активность современной молодёжи можно определить, как специфическую систему, то есть целостность взаимосвязанных и взаимообусловленных политических установок и действий молодых людей в возрасте от 14 до 30 лет, влияющих на её политическое мировоззрение, а также степень вовлеченности в политическую жизни общества.

Сам процесс формирования политической активности оказывает существенное влияние на развитие, функционирование и эволюцию государственных и общественных институтов и является потенциалом реализации конкретных политических установок.

\section{Библиография:}

1. Дроздов, А.Ю. Агрессивное поведение молодежи в контексте социальной ситуации / А.Ю. Дроздов // Социологические исследования. - 2003. - № 4;

2. Мартыненко, Б.К. Политический терроризм: понятие, признаки, классификации / Б.К. Мартыненко // СевероКавказский юридический вестник. - 1995. - № 7;

3. Сериков, А.В. Отношение молодежи Ростовской области к событиям в Москве и Беслане / А.В. Сериков // Путь в науку. Молодые ученые об актуальных проблемах социальных и гуманитарных наук. Вып.5. 4.2. Ростов н/Д., 2004;

4. Карпухин, О.И. Молодежь России: особенности социализации и самоопределения.: М., 2003. - С. 76.

5. Мяло К.Т. Время выбора: Молодежь и общество в поисках альтернативы. М.: Политиздат, 1991. - С. 111.

6. Кравченко, А.И. Социология. СПб.: Питер, 2010. C. 233.

7. Молодежь новой России: Аналитический доклад Института социологии РАН. Подготовлен в сотрудничестве с Представительством Фонда имени Фридриха Эберта в Российской Федерации. М., 2007.

8. Кара-Мурза, А.А. Цит. по: Политическая активность молодежи растет// Деловая пресса, Политический журнал. - 2005. - № 19.

9. Козенко, А. Молодежь рвет на части «Справедливую Россию» // Газета «Коммерсантъ» №29 (3605) от 22.02.2007.

10. Чертков, А.Н., Артамонова, Н.В. Региональный опыт функционирования «молодежного парламентаризма» 


\section{Право и политика 1 (157) 2013}

как механизма развития правовой культуры российских избирателей // Журнал российского права. - 2008. - № 1. С. 54

11. Киричек, А.И. К вопросу о дифференциации содержания категорий политическая активность, политическое поведение и политическое участие / А.И. Киричек // Общество: политика, экономика, право. - Краснодар: ИД «ХОРС», 2011. - №3. - С. 34-37.

12. О стратегии государственной молодежной политики в РФ: распоряжение Правительства РФ от 18 декабря 2006 г. №1760-p // Собрание законодательства РФ. 2006. - №52, ч. III, ст. 5622. - с. 16017-16026.

\section{References (transliteration):}

1. Drozdov, A.Yu. Agressivnoe povedenie molodezhi v kontekste sotsial'noy situatsii / A.Yu. Drozdov // Sotsiologicheskie issledovaniya. - 2003. - № 4;

2. Martynenko, B.K. Politicheskiy terrorizm: ponyatie, priznaki, klassifikatsii / B.K. Martynenko // SeveroKavkazskiy yuridicheskiy vestnik. - 1995. - № 7;

3. Serikov, A.B. Otnoshenie molodezhi Rostovskoy oblasti k sobytiyam v Moskve i Beslane / A.V. Serikov // Put' v nauku. Molodye uchenye ob aktual'nykh problemakh sotsial'nykh i gumanitarnykh nauk. Vyp.5. 4.2. Rostov n/D., 2004;

4. Karpukhin, O.I. Molodezh' Rossii: osobennosti sotsializatsii i samoopredeleniya.: M., 2003. - S. 76.

5. Myalo K.T. Vremya vybora: Molodezh' i obshchestvo v poiskakh al'ternativy. M.: Politizdat, 1991. - S. 111.

6. Kravchenko, A.I. Sotsiologiya. SPb.: Piter, 2010. - S. 233.

7. Kara-Murza, A.A. Tsit. po: Politicheskaya aktivnost' molodezhi rastet// Delovaya pressa, Politicheskiy zhurnal. - 2005. - № 19.

8. Kozenko, A. Molodezh' rvet na chasti «Spravedlivuyu Rossiyu» // Gazeta «Kommersant’» №29 (3605) ot 22.02.2007.

9. Chertkov, A.N., Artamonova, N.V. Regional'nyy opyt funktsionirovaniya «molodezhnogo parlamentarizma» kak mekhanizma razvitiya pravovoy kul'tury rossiyskikh izbirateley // Zhurnal rossiyskogo prava. - 2008. № 1. S. 54

10. Kirichek, A.I. K voprosu o differentsiatsii soderzhaniya kategoriy politicheskaya aktivnost', politicheskoe povedenie i politicheskoe uchastie / A.I. Kirichek // Obshchestvo: politika, ekonomika, pravo. - Krasnodar: ID «KhORS», 2011. - №3. - S. 34-37. 